\title{
Guidance on Determining Indispensability and Balancing Potential Benefits of Animal Experiments with Costs to the Animals with Specific Consideration of EU Directive 2010/63/EU
}

\author{
Toni Lindl ${ }^{1}$, Ulrike Gross ${ }^{2}$, Irmela Ruhdel ${ }^{2}$, Sonja von Aulock ${ }^{3}$, and Manfred Völkel ${ }^{4}$ \\ ${ }^{1}$ Institut für angewandte Zellkultur, Munich, Germany; ${ }^{2}$ German Animal Welfare Federation, Animal Welfare Academy, \\ Neubiberg, Germany; ${ }^{3}$ University of Konstanz, Germany; ${ }^{4}$ Tierversuchskommission Nordbayern, Government of Lower \\ Franconia, Würzburg, Germany
}

\begin{abstract}
Summary
Within the context of a workshop, a concept and practical guidance were developed that seek to balance potential benefits of animal experiments to humans, other animals, and the environment against the pain, suffering, and distress caused to the experimental animals. The aim was to achieve transparent decisions that can be communicated in a concise manner that is accessible to a layperson and is in accordance with German national law and EU Directive 2010/63/EU. The steps of the resulting decision process deal with the classification of procedures into the four severity levels, the consideration of humane endpoints, determination of the indispensability of the procedure on the basis of sound scientific argument, classification into applied or basic research, determination of the probability of success in the case of applied research, and the cost-benefit analysis, culminating in a decision on the approval or denial of the procedure.
\end{abstract}

Keywords: animal experiments, applications, cost-benefit analysis, Directive 2010/63/EU

\section{Introduction}

Directive 2010/63/EU on the protection of animals used for scientific purposes, which was endorsed in September 2010, replaces Directive 86/609/EEC on the protection of experimental animals of 1986. The new requirements must be implemented into national law by all Member States and be applied from January 1, 2013.

The Directive explicitly calls for an authorization procedure for animal experiments that must include "comprehensive project evaluation, taking into account ethical considerations in the use of animals" (EU, 2010, Recital 38). While many countries of the EU already require an ethically defensible relation between the expected benefits of the experiments and the expected burden on the animals, some currently do not. These states now need to introduce authorization procedures. The current German regulatory requirements on ethical assessment and balancing of interests may provide procedural suggestions for national adaptation of the Directive by other EU Member
States. German regulations are laid down in the German Animal Welfare Act (Germany, 2010, para 7,8) and the Administrative Regulation for its implementation (German Federal Ministry of Food, Agriculture and Consumer Protection, 2000). An authoritative and influential commentary on these regulations was published by Lorz and Metzger (2008, para 7 (54-59) and para 8 (19-22)).

Based on the Directive, the German Animal Welfare Act, and the commentary thereon, we here propose a formal procedure to simplify the evaluation of applications for animal experiments by participants in the authorization processes of animal experimentation. This procedure ensures an appraisal of the ethical and legal defensibility of the application by balancing the potential benefits for humans, animals, or the environment against the harm, pain, or distress to the experimental animals. We feel that, even if the details of national regulations vary, the essential points of ethical assessment remain the same. Our guide, therefore, may be adapted to national circumstances. The assessment, made on the basis of the information provided 
by the applicant and the designated veterinarian is sufficient for a layperson to understand the basis for the decision.

The informal and often grossly understated estimate of severity levels has been a persistent problem with applications for animal experiments in Germany. Assessments of the level of severity of animal experiments made by applicants for experimental procedures on animals using Annex 1 of the German Administrative Regulation for the Implementation of the Animal Protection Law (German Federal Ministry of Food, Agriculture and Consumer Protection, 2000) often have been irritating, with astounding differences, inconsistencies, and contradictions within the applications. For example, Völkel and Labahn (1997) showed blatantly contradictory estimates of pain levels in different passages within applications. They examined all applications submitted to a Consulting Commission between January 1991 and July 1995 and found that, in applications where researchers informally rated pain levels as nonexistent (no pain), more stringent analysis according to specified criteria yielded estimates of moderate to severe pain levels in $37 \%$ of the cases investigated. It is unlikely that this problem is specific to Germany.

To assure uniformity with regard to severity assessment, EU Directive 2010/63/EU defines four severity levels and provides examples for determining the severity level of different types of procedures (EU, 2010, Annex VIII, Section III). These examples can be used by participants in the authorization process of animal research to check the assessment made by the applicant. Reviewers are encouraged to form their own opinion of the cogency of the applicant's severity categorization.

The severity of experimental procedures must be considered in the cost-benefit analysis. "Costs" include the harm, pain, or distress caused to animals and/or "negative results." "Benefits" include the possible gain of knowledge and its potential to treat diseases.

The new EU Directive takes into account ethical norms and postulates that were not considered in the previous Directive. Animal ethicists have been demanding an upper limit for the pain, suffering, and distress to which animals are subjected in scientific procedures (Luy, 2005). Accordingly, the present Directive includes the clause that "the performance of procedures that result in severe pain, suffering or distress, which is likely to be long-lasting and cannot be ameliorated, should be prohibited." (EU, 2010, Recital 23).

The Directive allows such procedures only "for exceptional and scientifically justifiable reasons," subject to review by the European Commission (EU, 2010, Art 55 (3)). However, since Lindl et al. (2005) have shown that there is an inverse correlation between severity and usefulness of the results for humans, the authors take the position that procedures of such high severity cannot be ethically or even scientifically justified.

Among the legitimate purposes of animal experiments, the Directive includes procedures for education and training (EU, 2010, Article 5). This is a category of animal experiment for which the ethical justification seems a formidable problem, since the Directive also states, "the use of animals for scientific or educational purposes should [...] only be considered where a non-animal alternative is unavailable" (EU, 2010, Recital 12). There are numerous alternative ways and means to achieve educational goals as compiled in the databases of InterNICHE ${ }^{1}$, NORECOPA $^{2}$, and eurca ${ }^{3}$. Applications for the use of animals for this purpose must therefore include a detailed and carefully documented explanation of why existing alternative methods are not acceptable.

\section{Guidance on the proposed procedure}

Answering the questions in the following categories $\mathrm{A}$ to $\mathrm{F}$ in sequence on the basis of the application and/or the opinion of the designated veterinarian leads to an appraisal $\mathrm{G}$ of the experimental proposal (see Box 1):

A: Determination of the level of severity

B: Consideration of humane endpoints

$\mathrm{C}$ : Determination of the indispensability of the experimental proposal

D: Classification into applied or basic research

E: Determination of the probability of success and/or proof of the hypothesis

F: Cost-benefit analysis

G: Appraisal

This procedure represents an important step towards recognizing unjustifiable research proposals, determining the relevant level of severity, and differentiating between research performed on proven/validated or unexplored animal models in applied and basic research to reach a statement on the scientific value of an experimental proposal.

\section{A Determination of the level of severity}

In this first step of the evaluation of the ethical defensibility of an application, the level of severity must be determined. Here the burden on the experimental animal group with the highest level of severity in the procedure is decisive.

If the application and the opinion of the designated veterinarian do not contain concise statements on the harm, pain, or distress caused to the experimental animals, the application must be designated incomplete and be returned to the applicant as non-assessable. The designated veterinarian's severity classification is decisive in cases of doubt.

The EU Directive stipulates that

- "Member States may, while observing the general rules laid down in the TFEU [Treaty on the Functioning of the European Union], maintain provisions in force on 9 November 2010, aimed at ensuring more extensive protection of animals falling within the scope of this Directive than those contained in this Directive." (EU, 2010, Article 2)

\footnotetext{
1 http://www.interniche.org/en/home

2 http://oslovet.norecopa.no/fag.aspx?fag=57\&mnu=databases_1

3 http://www.eurca.org/
} 
- "Member States shall ensure that, wherever possible, a scientifically satisfactory method or testing strategy, not entailing the use of live animals, shall be used instead of a procedure." (EU, 2010, Article 4(1))

- "Member States shall ensure that the number of animals used in projects is reduced to a minimum without compromising the objectives of the project." (EU, 2010, Article 4(2))

- "Without prejudice to national legislation prohibiting certain types of methods, Member States shall ensure that a procedure is not carried out if another method or testing strategy for obtaining the result sought, not entailing the use of a live animal, is recognised under the legislation of the Union." (EU, 2010, Article 13(1))

- "In choosing between procedures, those which to the greatest extent meet the following requirements shall be selected:

(a) use the minimum number of animals;

(b) involve animals with the lowest capacity to experience pain, suffering, distress or lasting harm;

(c) cause the least pain, suffering, distress or lasting harm; and are most likely to provide satisfactory results." (EU, 2010, Article 13(2))

- "Member States shall ensure that all procedures are classified as 'non-recovery', 'mild', 'moderate', or 'severe' on a caseby-case basis using the assignment criteria set out in Annex VIII." (EU, 2010, Article 15 (1))

- "Subject to the use of the safeguard clause in Article 55(3), Member States shall ensure that a procedure is not performed if it involves severe pain, suffering or distress that is likely to be long-lasting and cannot be ameliorated." (EU, 2010, Article 15(2)).

Severity categories according to Directive 2010/63/EU:

- "Non-recovery:

Procedures which are performed entirely under general anaesthesia from which the animal shall not recover consciousness shall be classified as 'non-recovery'.

- Mild:

Procedures on animals as a result of which the animals are likely to experience short-term mild pain, suffering or distress, as well as procedures with no significant impairment of the well-being or general condition of the animals shall be classified as 'mild'.

- Moderate:

Procedures on animals as a result of which the animals are likely to experience short-term moderate pain, suffering or distress, or long-lasting mild pain, suffering or distress as well as procedures that are likely to cause moderate impairment of the well-being or general condition of the animals shall be classified as 'moderate'.

- Severe:

Procedures on animals as a result of which the animals are likely to experience severe pain, suffering or distress, or longlasting moderate pain, suffering or distress as well as procedures, that are likely to cause severe impairment of the wellbeing or general condition of the animals shall be classified as "severe."
Even though the Directive explicitly includes only these four levels of severity, a fifth level exceeding "severe" is mentioned (EU, 2010, Art.15(2)): a "procedure involve [ing] severe pain, suffering or distress that is likely to be long-lasting and cannot be ameliorated." Such procedures should be prohibited (EU, 2010, Recital 23), subject to exceptions according to Art 55(3): "Where, for exceptional and scientifically justifiable reasons, a Member State deems it necessary to allow the use of a procedure involving severe pain, suffering or distress that is likely to be long-lasting and cannot be ameliorated, as referred to in Article 15(2), it may adopt a provisional measure to allow such procedure." The practical guide proposed here disregards this exception, since these cases are expected to be rare.

\section{B Consideration of termination criteria}

An experimental animal that experiences severe suffering should be taken out of the experiment and killed by a competent person to avoid further suffering (EU, 2010; Recitals 13, 14, and 15; Article 13(3b)). Therefore, applicants musts formulate criteria for humane endpoints that ensure that, in the case of animals experiencing severe suffering and death, the duration of this suffering is as short as possible. This includes detailing of:

- Clear severity criteria for humane endpoints

- The monitoring cycles, i.e., the maximum time that the animal must suffer until the endpoint is diagnosed. The monitoring cycles should be defined as once per day, multiple times per day, or hourly and should be differentiated for weekdays, Saturdays, Sundays, and public holidays.

\section{Determination of the indispensability}

Directive 2010/63/EU provides that: "Member States shall ensure that, wherever possible, a scientifically satisfactory method or testing strategy, not entailing the use of live animals, shall be used instead of a procedure." (EU, 2010, Article 4(1) and Article 13(1)). The researcher should show that he/she has consulted the available literature for alternative ways to address his/her scientific question, and should give reasons why these approaches are not feasible. A good example for a convincing argument would be a demonstration (backed by relevant literature) that certain partial aspects of the research have already been addressed in organ cultures or with other methods, the reasons that these methods can be carried no further, and that the animal experiment is based on these experiments, capping a research strategy. It must be evaluated whether the applicant has argued sufficiently that the goal of the experimental procedure cannot be reached with alternative test methods.

\section{Classification into purpose of research}

The correct classification of the research purpose, considered together with the severity of the procedure, is of critical importance in the ethical assessment. The new Directive differentiates between basic research (EU, 2010, Article 5a, see D2), translational or applied research, and experiments for educational and 
forensic purposes (EU, 2010, Article 5b-g). Basic research and experiments for education have to meet more stringent ethical demands, in that they can justify severe procedures only in exceptional cases.

Basic research is not driven by economic interests nor does it aim to apply the result of the research (in contrast to therapyoriented or pharmaceutical research). It is not goal-oriented but aims to increase general scientific knowledge. For the purposes of this practical guide, basic research is defined by exclusion: it is not translational or applied.

Translational or applied research, on the other hand, can be identified by the fact that use and applicability can be scientifically demonstrated. This means that, for an animal model to qualify as translational, scientific literature should exist, showing, for example, that diagnostic means or therapies based on this model have been successfully used in humans. Speculation as to potential translational possibilities is insufficient to qualify research as translational. Examples for goals of applied research are listed in the Directive (EU, 2010, Article 5).

\section{E Determination of the probability of success and/or proof of the hypothesis}

The commentary on the German Animal Welfare Act states that the aim of the procedure is inseparable from achievement of the results expected from the experimental procedure (Lorz and Metzger, 2008, para 7 (56, last sentence)). Therefore it must be determined for applications in the area of applied research whether the proposed animal model can deliver results that may be transferable to humans, animals or the environment (Rippe, 2009, 3.3).

The probability of success can only be determined if the applicant has justified the experimental project scientifically, especially regarding the use of the animal model. If scientific literature can be cited which demonstrates that the proposed animal model previously delivered results that were transferable to humans, animals, or the environment when used for the same or a similar experimental approach, the probability of attaining transferable results may be assumed.

If the clinical relevance of the animal model cannot be supported with scientific literature, then it cannot be assumed that transferable results will be obtained.

Scientific citations used to justify the proposed animal model must demonstrate specifically that this animal model used in this discipline with the same or similar research questions previously delivered transferable results that made a significant contribution to a new therapeutic approach. Citations that do not fulfill these criteria are insufficient to demonstrate this information. The value of a citation within the discipline and whether the animal model does provide transferable results often can be clarified only by assessing the cited study. Abstracts, and sometimes the full articles, are available free of charge on scientific databases like Pubmed or zbmed.de. A citation by itself is no indication of the scientific merit of the proposed animal model and should therefore be critically evaluated.

It is a legal requirement in both applied and basic research that the expected result must be of importance in the respective scientific discipline. It must not only answer the questions posed in the application but must also help to solve important scientific problems (Lorz and Metzger, 2008, para 8 (12)).

\section{F Cost-benefit analysis}

A justifiable balance is required between the needs of humans, animals, or the environment and the pain, suffering, and distress of animals proposed to meet these needs. The more severe an experimental procedure is, the greater must be the weight of the legitimizing reasons (Lorz and Metzger, 2008, para 7 (57, second sentence)). If all formal and material requirements are fulfilled, even a procedure in the field of basic research classified as of moderate severity may be approved.

\section{G Appraisal}

The answers to the questions lead to:

- G1: The application fulfills the regulatory requirements of the cost-benefit analysis. It is probable that the aim of the procedure will be reached, the level of severity is balanced with the expected benefit for humans, animals or the environment and can be approved (EU, 2010, Annex VIII; Germany, 2010, para 7,8; Lorz and Metzger, 2008 para 7 (54-59) and para 8 (19-23)).

or

- G2: The application does not fulfill the regulatory requirements of the cost-benefit analysis in its current form. It does not fulfill the requirements for the ethical defensibility of the use of vertebrates for scientific purposes (EU, 2010, Annex VIII; Germany, 2010, para 7,8; Lorz and Metzger, 2008 para 7 (54-59) and para 8 (19-23)) and therefore

a) is denied for the reasons given or

b) in the case of open questions, incomplete or inconsistent data is deferred with a request for response from the applicant.

\section{Practical examples}

The practical examples given here were taken from real applications for animal experiments but are anonymized and summarized. Examples 1 and 2 deal with applied research; examples 3-7 deal with basic research. The project evaluation was done using the proposed guideline (Box 1) and is in accordance with Article 38 1(a) and 2(a) (EU, 2010).

\section{Example 1}

An experimental procedure is intended to deliver new therapeutic approaches for the improved treatment of patients. The experiment shall be performed in mice, as the research goal can only be reached in intact organisms, and an animal model is therefore necessary. The following explanation is given: In this research area, the mouse is internationally established as the smallest possible mammal on which the procedure can be performed; the lesions in the mouse are comparable to those in humans to such an extent that results from in vivo experiments can be transferred to the human pathophysiological situation, but this statement is not backed by scientific literature. The level of severity is "moderate." 
Box 1: Form for the cost-benefit analysis of proposed experimental scientific procedures on animals

\section{Application/Procedure number}

\begin{tabular}{|l|l|l|l|}
\hline A & \multicolumn{3}{|l|}{$\begin{array}{l}\text { Determination of the level of severity of the experimental animal group with the highest level of } \\
\text { severity in the procedure (Directive 2010/63/EU, Annex VIII) according to information given in the opinion of } \\
\text { the designated veterinarian }\end{array}$} \\
\hline$\square$ & A1 & Non-recovery*: & $\begin{array}{l}\text { Procedures which are performed entirely under general anaesthesia from which the animal shall not } \\
\text { recover consciousness shall be classified as 'non-recovery'. }\end{array}$ \\
\hline$\square$ & A2 & Mild*: & $\begin{array}{l}\text { Procedures on animals as a result of which the animals are likely to experience short-term mild pain, } \\
\text { suffering or distress, as well as procedures with no significant impairment of the well-being or general } \\
\text { condition of the animals shall be classified as 'mild'. }\end{array}$ \\
\hline$\square$ & A3 & Moderate*: & $\begin{array}{l}\text { Procedures on animals as a result of which the animals are likely to experience short-term moderate } \\
\text { pain, suffering or distress, or long-lasting mild pain, suffering or distress as well as procedures } \\
\text { that are likely to cause moderate impairment of the well-being or general condition of the animals } \\
\text { shall be classified as 'moderate'. }\end{array}$ \\
\hline$\square$ & A4 & $\begin{array}{l}\text { Severe*: } \\
\text { Procedures on animals as a result of which the animals are likely to experience severe pain, } \\
\text { suffering or distress, or long- lasting moderate pain, suffering or distress as well as procedures, that } \\
\text { are likely to cause severe impairment of the well- being or general condition of the animals shall } \\
\text { be classified as 'severe'. }\end{array}$ \\
\hline
\end{tabular}

$\square$ mark as appropriate; * according to Directive 2010/63/EU, Annex VIII

Note: If the opinion of the designated veterinarian is lacking: "Application incomplete, return to applicant". Perform own appraisal of severity level, see Directive 2010/63/EU Annex VIII, Section III, Examples of different types of procedure.

Comments:

\begin{tabular}{|c|c|c|c|}
\hline B & $\begin{array}{l}\text { Designation of humane endpoints given in the application (2010/63/E } \\
\text { Art. } 13 \text { Paragraph } 3\end{array}$ & cital 5 & 15; 23; and 30; \\
\hline B1 & $\begin{array}{l}\text { Non-recovery procedure: humane endpoints are not relevant. } \\
\text { Animals are killed under anaestesia }\end{array}$ & $\begin{array}{l}\text { Yes } \square \\
\text { No } \square\end{array}$ & $\begin{array}{l}\text { Continue with } \mathrm{C} \\
\text { Continue with } \mathrm{B} 2\end{array}$ \\
\hline B2 & $\begin{array}{l}\text { Procedure classified as "mild" or "moderate" in the application: if in } \\
\text { the course of the experiment a "severe" level suffering occurs, the animal } \\
\text { is taken out of the experiment immediately and killed without causing } \\
\text { any further suffering }\end{array}$ & $\begin{array}{l}\text { Yes } \square \\
\text { No } \square\end{array}$ & $\begin{array}{l}\text { Continue with } \mathrm{C} \\
\text { Continue with B3 }\end{array}$ \\
\hline B3 & $\begin{array}{l}\text { procedure classified as "severe" } \\
\text { It is possible that the criteria for the humane endpoints surpass upper } \\
\text { limit of the category "severe" (such procedures are prohibited, EU, 2010, } \\
\text { Recital, 23) }\end{array}$ & $\begin{array}{l}\text { Yes } \square \\
\text { No } \square\end{array}$ & $\begin{array}{l}\text { Continue with } \mathrm{G} 2 \\
\text { Continue with } \mathrm{C}\end{array}$ \\
\hline
\end{tabular}

$\square$ mark as appropriate

Comments: 


\begin{tabular}{|l|l|l|l|}
\hline C & Determination of the indispensability (Lorz and Metzger, 2008, para. 7 (35-39); 2010/63/ EU Art 4 (1); Art 13 (1)) \\
\hline C & $\begin{array}{l}\text { The applicant has argued convincingly that no scientifically sufficient, } \\
\text { justifiable and practicable alternatives such as cell and tissue cultures, } \\
\text { computer programs or respective in vitro tests are available. }\end{array}$ & Yes $\square$ & Continue with D \\
No $\square$ & Continue with G2 \\
\hline
\end{tabular}

$\square$ mark as appropriate

\begin{tabular}{|l|l|l|l|}
\hline D & \multicolumn{2}{|l|}{ Classification into purpose of procedure: translational or basic research (2010/63/EU Art. 5) } \\
\hline D1 & $\begin{array}{l}\text { The experimental procedure is carried out for the purpose of translational } \\
\text { or applied research (2010/63/EU Article 5 b, c, or g) }\end{array}$ & $\begin{array}{l}\text { Yes } \square \\
\text { No }\end{array}$ & $\begin{array}{l}\text { Continue with E } \\
\text { Continue with D2 }\end{array}$ \\
\hline D2 & $\begin{array}{l}\text { The experimental procedure is carried out for the purpose of translational } \\
\text { or applied research - protection of the environment or of species diversity } \\
\text { (2010/63/EU Article 5(d) and (e)) }\end{array}$ & Yes $\square$ & Continue with E \\
\hline D3 & $\begin{array}{l}\text { The experimental procedure is carried out for the purpose of higher } \\
\text { education or training (2010/63/EU Article 5(f)) }\end{array}$ & Yes $\square$ & Continue with F1.1 \\
\hline D4 & $\begin{array}{l}\text { The experimental procedure is carried out for the purpose of basic } \\
\text { research (2010/63/EU Article 5a) }\end{array}$ & No $\square$ & Yes $\square$ \\
\hline
\end{tabular}

$\square$ mark as appropriate

\section{Comments:}

\begin{tabular}{|c|c|c|c|c|}
\hline \multirow{2}{*}{$\begin{array}{l}\mathbf{E} \\
\mathrm{E} 1\end{array}$} & \multicolumn{4}{|c|}{$\begin{array}{l}\text { The educational value or the probability of delivering results that are transferable to humans, other animals, } \\
\text { or the environment or of delivering clinically relevant results in this scientific discipline using this experimental } \\
\text { procedure (EU, 2010, Art } 13(2 \mathrm{c}) \text { ) }\end{array}$} \\
\hline & $\begin{array}{l}\text { Can be assumed } \\
\text { because }\end{array}$ & $\begin{array}{l}\text { The transferability of results from experimental } \\
\text { procedures to humans, animals, or the environment in } \\
\text { this scientific discipline has previously been de- } \\
\text { monstrated for the same or a similar research question } \\
\text { and is argued using the relevant scientific literature, } \\
\text { or the educational value has been argued convincingly }\end{array}$ & $\begin{array}{l}\text { Yes } \square \\
\text { No } \square\end{array}$ & $\begin{array}{l}\text { Continue with F1 } \\
\text { Continue with E2 }\end{array}$ \\
\hline E2 & $\begin{array}{l}\text { Is unclear } \\
\text { because }\end{array}$ & $\begin{array}{l}\text { Newly created genetically modified animals are } \\
\text { to be used where relevance cannot be predicted } \\
\text { And/or the literature quoted is insufficient, or } \\
\text { the educational value is doubtful }\end{array}$ & $\begin{array}{l}\text { Yes } \square \\
\text { No } \square\end{array}$ & $\begin{array}{l}\text { Continue with F2 } \\
\text { Continue with E3 }\end{array}$ \\
\hline E3 & $\begin{array}{l}\text { Is unlikely } \\
\text { because }\end{array}$ & $\begin{array}{l}\text { The transferability of results from the proposed animal } \\
\text { model to humans, other animals or the environment in } \\
\text { this scientific discipline has not previously been } \\
\text { shown based on the scientific literature cited in } \\
\text { the proposal, or the educational value is lacking. }\end{array}$ & Yes $\square$ & Continue with F3 \\
\hline
\end{tabular}

$\square$ mark as appropriate

\section{Comments:}




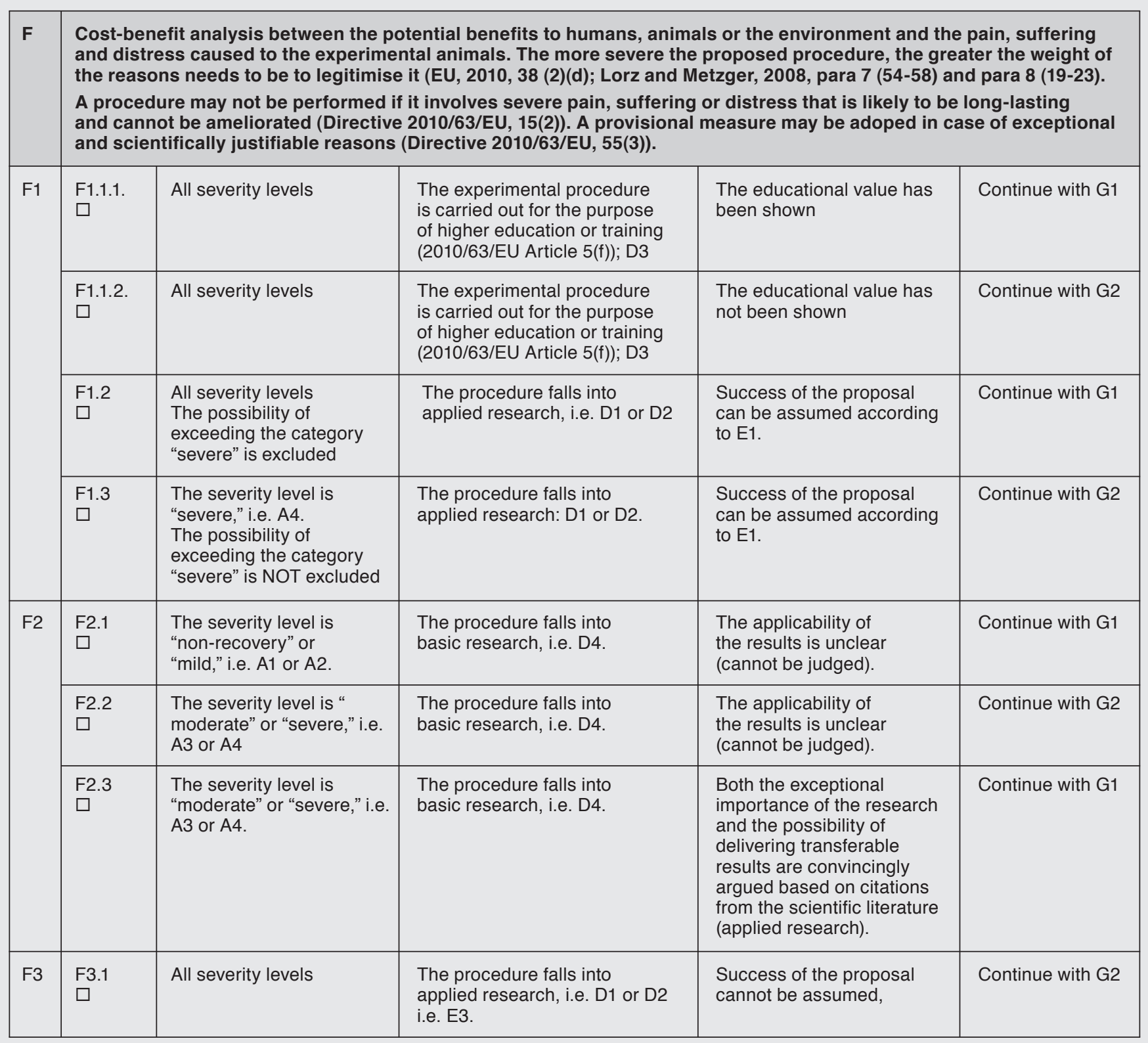

$\square$ mark as appropriate

Comments: 
If in the course of the experiment, the suffering of the animal reaches a "severe" level, the animal is taken out of the experiment and sacrificed. The experiments might deliver the basis for new therapies.

\section{Evaluation:}

\begin{tabular}{|l|l|}
\hline A3 & The severity level is "moderate." \\
\hline B2 & $\begin{array}{l}\text { Reaching a "severe" level is given as the termination } \\
\text { criterion. }\end{array}$ \\
\hline C & \begin{tabular}{l} 
The indispensability is shown. \\
\hline D1
\end{tabular} \\
\hline The experiment falls into the area of applied research. \\
\hline F3.1 & $\begin{array}{l}\text { It cannot be assumed that transferable results } \\
\text { will be attained. }\end{array}$ \\
\hline G2 & The outcome of the cost-benefit analysis is negative. \\
\hline
\end{tabular}

\section{Explanation:}

Aim of the application is to deliver the basis for new therapies. Its purpose is translational or applied research (EU, 2010, Article $5(\mathrm{~b}))$.

According to the Directive "In choosing between procedures, those [...] most likely to provide satisfactory results [shall be selected]" (EU, 2010, Art 13(2c)). Here, an animal model was selected for which it has NOT been shown, by citing scientific literature, that the chosen mouse model has yielded results that were translatable to humans. Therefore, probable success cannot be assumed. (Lorz and Metzger, 2008, para 7 (56, last sentence) and Rippe, 2009, 3.3).

The application does not fulfill the regulatory requirements of the cost-benefit analysis in its current form

(Germany, 2010, para 7(2-3) and 8(2.1)). It does not fulfill the requirements for the ethical defensibility of the use of vertebrates for scientific purposes and must be denied (Lorz and Metzger, 2008, para 7 (54-58) and para 8 (19-23)).

\section{Example 2}

As Example 1, but in addition the applicant has given a scientific explanation backed by relevant citations from the literature that shows that the animal model (mouse) has already provided data on the same or similar research questions that were transferable to humans.

\section{Evaluation:}

\begin{tabular}{|c|c|}
\hline A3 & The severity level is "moderate." \\
\hline B2 & $\begin{array}{l}\text { Reaching a "severe" level is given as the termination } \\
\text { criterion. }\end{array}$ \\
\hline C & The indispensability is shown. \\
\hline D1 & The experiment falls into the area of applied research. \\
\hline E1 & $\begin{array}{l}\text { It can be assumed that transferable results will be } \\
\text { attained for the postulated goal. }\end{array}$ \\
\hline $\mathrm{F} 1.2$ & The outcome of the cost-benefit analysis is positive. \\
\hline G1 & $\begin{array}{l}\text { The application fulfills the requirements and can be } \\
\text { approved. }\end{array}$ \\
\hline
\end{tabular}

\section{Explanation:}

The animal model most likely to provide satisfactory results is to be used. The application fulfills the regulatory requirements of the cost-benefit analysis. It is probable that the aim of the experiment will be reached, the level of severity is balanced with the expected benefit for humans and can therefore be approved (EU, 2010, Article 13(2c) and Article 38(2d); Lorz and Metzger, 2008, para 7 (54-58) and para 8 (19-23)).

\section{Example 3}

The basis for the prevention and therapy of chronic transplant rejection shall be investigated by specific modulation of the immune response in addition to treatment of the acute rejection response. Clinical experience allows assessment of the relevance of experimental results. Systematic differentiation of the role of alloantigen-dependent and -independent influencing variables on the chronic rejection reaction is only possible by using inbred rat or mouse strains. The XY-transplantation is internationally established in the rat model. Although the animal receives continuous postoperative analgesic therapy, the procedure is classified as "severe." The experiment falls into the field of basic research, but is directed towards prevention and therapy of chronic transplantation rejection reactions. The animal is to be taken out of the experiment and sacrificed in case of a strong reduction of food or water intake, weight loss (more than 20\%), shaggy coat, labored breathing, fever, and other behavioral changes.

\section{Evaluation:}

\begin{tabular}{|l|l|}
\hline A4 & The severity level is "severe". \\
\hline B3 & A further deterioration is given as termination criterion. \\
\hline C & The indispensability is shown. \\
\hline D4 & The experiment falls into the area of basic research. \\
\hline E & Not applicable for basic research \\
\hline F2.2 & The outcome of the cost-benefit analysis is negative. \\
\hline G2 & The application must be denied. \\
\hline
\end{tabular}

\section{Explanation:}

Although the aim of the proposed experiment is to deliver a basis for the prevention and therapy of chronic transplantation rejection reactions, it is classified as basic research according to Article 5(a) of Directive 2010/63 (EU, 2010). Both the "severe" level and the further deterioration given as termination criterion are ethical grounds for denying the application (EU, 2010, Article 15(2); Lorz and Metzger, 2008, para 7(56); Rippe, 2009, 3.3)

\section{Example 4}

The application is a direct continuation of an experimental procedure that has been previously approved. Now, however, mouse strains shall be used that were generated using new gene constructs (gene knockdown), because this technique saves a large number of animals and much time in providing the mice with the required genetic characteristics. 
The severity level is "mild" to "moderate." However, the prospective severity level is difficult to judge, as newly created genetically modified mice are to be used. If there are indications that the genetic modification itself causes significant health problems to the animals, the strain will not be used for experiments of longer duration.

The described experimental goals cannot be reached without the use of genetically modified animal models.

It can be expected that the experiments will deliver new insights into the disease $\mathrm{XY}$ und will provide a basis for new therapeutic approaches to the disease XY, which constitutes a common cause of death in the western world.

\section{Evaluation:}

\begin{tabular}{|l|l|}
\hline A3 & The severity level is "mild" to "moderate". \\
\hline B2 & $\begin{array}{l}\text { Reaching a "severe" level is given as the termination } \\
\text { criterion. }\end{array}$ \\
\hline C & The indispensability is shown. \\
\hline D4 & The experiment falls into the area of basic research. \\
\hline E & Not applicable for basic research \\
\hline F2.2 & The outcome of the cost-benefit analysis is negative. \\
\hline G2 & The application must be denied. \\
\hline
\end{tabular}

Explanation:

The aim of the experiment is to provide a basis for new therapeutic strategies. Because the project aims to use newly created, genetically modified mice, there is no scientific basis to support that the model can be successful in reaching the postulated aim. Even though the method may be backed by scientific literature and the applicant may have extensive experience with the animal model, this does not show clinical relevance of the model to provide results that could be of significant value in the research area in question. Therefore, the project is classified as basic research according to EU, 2010, Art. 5(a) and must be denied on account of the severity level that is not justified by convincing arguments for the transferability of possible results.

\section{Example 5}

An animal experiment shall provide new insights into certain molecular mechanisms and open new possibilities for pharmacological modulation. It falls into the field of basic research. The experiments shall be performed on the rat, as it cannot be performed on humans for ethical reasons. The rat model is internationally established in this area of research. The severity level is "mild." If a "moderate" level is reached, the animal shall be taken out of the experiment and sacrificed.

\section{Evaluation:}

\begin{tabular}{|l|l|}
\hline A2 & The severity level is "mild." \\
\hline B2 & $\begin{array}{l}\text { Reaching a "moderate" level is given as } \\
\text { the termination criterion. }\end{array}$ \\
\hline C & The indispensability is shown. \\
\hline
\end{tabular}

\begin{tabular}{|l|l|}
\hline D4 & The experiment falls into the area of basic research. \\
\hline E & Not applicable for basic research \\
\hline F2.1 & \begin{tabular}{l} 
The outcome of the cost-benefit analysis is positive. \\
\hline G1
\end{tabular} \\
$\begin{array}{l}\text { The application fulfills the requirements and can } \\
\text { be approved. }\end{array}$ \\
\hline
\end{tabular}

\section{Explanation:}

The aim of the experiment is to increase medical knowledge. The severity level "mild," together with the termination criterion (reaching a "moderate" level) fulfill the criteria for ethical defensibility in their current form.

The animal model most likely to provide satisfactory results is to be used. The application fulfills the regulatory requirements of the cost-benefit analysis. It is probable that the aim of the experiment will be reached, the level of severity is balanced with the expected benefit for humans and can therefore be approved (EU, 2010, Article 13(2c) and Article 38(2d); Lorz and Metzger, 2008, para 7 (54-58) and para 8 (19-23)).

\section{Example 6}

The applicant aims to develop a basis for new therapeutic options with the proposed experiment. The level of severity is "moderate" to "severe." If the level reaches "severe," the animal will be taken out of the experiment immediately and sacrificed. The animals are monitored every four hours, also on weekends. The experiments shall be performed on $30 \mathrm{dogs}$ and 3 primates. The scientist has done research on these animal models for more than 15 years in the area of basic research. The research cannot be done on humans for ethical reasons.

\section{Evaluation:}

\begin{tabular}{|l|l|}
\hline A4 & The severity level is "moderate" to "severe" \\
\hline B3 & $\begin{array}{l}\text { Reaching a "severe" level is given as the termination } \\
\text { criterion. }\end{array}$ \\
\hline C & The indispensability is shown. \\
\hline D4 & The experiment falls into the area of basic research. \\
\hline E & Not applicable for basic research \\
\hline F2.2 & The outcome of the cost-benefit analysis is negative. \\
\hline G2 & The application must be denied. \\
\hline
\end{tabular}

Explanation:

The aim of the experiment is to provide a basis for application in humans. Medical knowledge shall be increased. Both the "moderate" severity level and the possibility of a "severe" level argue for denying the application on ethical grounds. The aim of the experiment, as positioned and rated in the scientific area by the applicant, does not ratify the severity level "moderate" to "severe" (EU, 2010, Article 15(2); Lorz and Metzger, 2008, para 7 (54-58) and para 8 (19-23)). 


\section{Example 7}

As in example 6, but the applicant explains the exceptional importance of the research. The exceptional importance is documented with scientific citations that clearly demonstrate that the results of the applicant's research have previously contributed to the initiation of clinical studies and were seminal in the development of new therapies.

\section{Evaluation:}

\begin{tabular}{|l|l|}
\hline A4 & The severity level is "moderate" to "severe" \\
\hline B3 & $\begin{array}{l}\text { Reaching a "severe" level is given as the termination } \\
\text { criterion. }\end{array}$ \\
\hline C & The indispensability is shown. \\
\hline D4 & $\begin{array}{l}\text { The experiment falls into the area of basic research. } \\
\text { E } \\
\text { produce transferable results }\end{array}$ \\
\hline F2.3 & $\begin{array}{l}\text { The outcome of the cost-benefit analysis is positive, } \\
\text { based on exceptional importance of the research } \\
\text { and convincing arguments for delivery of transferable } \\
\text { results. }\end{array}$ \\
\hline G1 & $\begin{array}{l}\text { The application fulfills the requirements and can } \\
\text { be approved. }\end{array}$ \\
\hline
\end{tabular}

\section{Explanation:}

The aim of the experiment is to provide a basis for application in humans. Medical knowledge shall be increased.

Both the "moderate" severity level and the possibility of a "severe" level as such argue for denying the application on ethical grounds. But, because the applicant has argued the exceptional importance of his research, that his previous results with these animal models have already delivered transferable results for humans and were of high value for the development of new therapies, this experiment does fulfill the ethical criteria despite the severity levels "moderate" to "severe." The application fulfills the regulatory requirements of the cost-benefit analysis. It is probable that the aim of the experiment will be reached, the level of severity is balanced with the expected benefit for humans and can therefore be approved (EU, 2010, Article 13(2c) and Article 38(2d); Lorz and Metzger, 2008, para 7 (54-58) and para 8 (19-23)).

\section{Conclusion}

When examining an application for animal experiments and balancing the merits of a proposal against the pain, suffering, distress, and harm to the animal, the weight of specialist scientific knowledge generally is brought to bear in favor of the experiment to be performed. Non-specialists having to assess the claims of experienced researchers are often in a difficult position to argue against this.

Based on the EU-Directive, this practical guide provides suggestions on how to assess the various aspects of applications for animal experimentation procedures, and on how such an assessment can be structured. In justice to the animals that suffer as stand-ins for human beings, stringent standards should be applied. If, as a result, the scientific reasoning in the applications becomes more rigorous, it is not only the animals that profit, but science, also.

\section{References}

EU - European Union (2010). Directive 2010/63/EU of the European Parliament and of the Council of 22 September 2010 on the protection of animals used for scientific purposes. Official J. EU L 276, 33-79. http://eur-lex.europa.eu/ LexUriServ/LexUriServ.do?uri=OJ:L:2010:276:0033:0079: EN:PDF

German Federal Ministry of Food, Agriculture and Consumer Protection (2000). Allgemeine Verwaltungsvorschrift zur Durchführung des Tierschutzgesetzes. http://www.verwaltungsvorschriften-im-internet.de/ bsvwvbund_09022000_32135220006.htm

Germany (2010). Tierschutzgesetz in der Fassung der Bekanntmachung vom 18. Mai 2006 (BGB1. I S. 1206, 1313), das zuletzt durch Artikel 20 des Gesetzes vom 9. Dezember 2010 (BGB1. I S. 1934) geändert worden ist. http://www. gesetze-im-internet.de/bundesrecht/tierschg/gesamt.pdf

Lindl, T., Völkel, M., and Kolar, R. (2005). Tierversuche in der biomedizinischen Forschung (Animal experiments in biomedical research. An evaluation of the clinical relevance of approved animal experimental projects). ALTEX 22, 143151.

Lorz and Metzger (2008). Tierschutzgesetz - Kommentar. $6^{\text {th }}$ edition. Munich, Germany: C. H. Beck.

Luy, J. (2005). Das ethische Mindestmaß beim Tierschutz. Berl. Münch. Tierärztl. Wschr. 118, 89-94.

Rippe, K. P. (2009). Güterabwägungen im Tierversuchsbereich. Anmerkungen zu einem ethischen Paradigmenwechsel (Weighing of interests in justifying animal experiments. Comments on a shift in ethical paradigms). ALTEXethik 1, 3-10.

Völkel, M. and Labahn, D. (1997). Die Belastung der Versuchstiere nach Einschätzung der Antragsteller von Versuchsge-nehmigungen - Forderung von Kriterien zur ethischen Rechtsanwendung. In H. Schöffl, H. Spielmann, and H. A. Tritthardt (eds.), Ersatz- und Ergänzungsmethoden zu Tierversuchen, Forschung ohne Tierversuche. Vienna, New York: Springer, 395-405.

\section{Acknowledgements}

The authors would like to thank Dr Franz P. Gruber and Manfred Schmitt for their valuable help in preparing this manuscript.

\section{Correspondence to}

Toni Lindl, $\mathrm{PhD}$

Institut für angewandte Zellkultur

Balanstr. 6, 81669 München

Germany

e-mail: I-A-Z@t-online.de 